\title{
TOWARDS PROVIDING EFFECTIVE ACADEMIC LITERACY INTERVENTION
}

\author{
TJ van Dyk \\ University of Stellenbosch
}

This article focuses on the current situation in South Africa in which a number of factors related to academic literacy deleteriously affect student throughput. This has large financial implications for the country as well as tertiary institutions. Since significant numbers of students with high academic potential are at risk because of their low levels of academic literacy, all first year students at three South African universities write the Test of Academic Literacy Levels (TALL). This test can be used to assign students to appropriate support courses. An explanation illustrated by empirical data is given of the construct and the use of TALL. Preliminary conclusions in terms of the impact of the intervention are drawn as first iteration towards an in-depth longitudinal study to test the effectiveness/success of the academic literacy intervention. Finally suggestions for further research are outlined.

\section{INTRODUCTION}

Low levels of academic literacy in the language of learning are widely seen as one of the main reasons for the lack of academic success' among South African undergraduate students with high academic potential (Blacquiére, 1989, Leibowitz, 2001; Perkins 1991, Pretorius, 1995; Vorster \& Reagan, 1990; van Rensburg \& Weideman, 2002). One obvious reason is that students with low levels of academic literacy will have a great deal of difficulty in dealing with prescribed academic material.

Research done by independent educational specialists suggests that there has been a dramatic drop in the level of (academic) language proficiency among students who apply for tertiary study (cf. Rademeyer, 2005a:40; Natal Witness, 2004:8). Based on data from the South African Department of Education (DoE), Mamaila (2001:1) observes that 25\% of first year tertiary enrolments drop out before completing their studies. This represents a financial loss of approximately R1, 3 billion a year. Even more dramatic figures are quoted by Mkhabela and Malan (2004:2) who point out that not only has the percentage of first year dropouts increased, but $40 \%$ of historically disadvantaged students drop out. The situation remains critical in the subsequent years of the undergraduate programme, since the challenges increase. Rademeyer (2005b:4) reports that between 2000 and 2002, 50\% of all tertiary students failed, and between 2002 and 2003 only $22 \%$ graduated.

There are several reasons for the situation described above. However, for purposes of this article, three will be discussed. The first of these is the political history of segregation and subsequent unequal distribution of resources in the South African educational system that has 
negatively affected a large group of students - commonly referred to as historically disadvantaged students - and often considered as one of the main reasons for academic failure (Butler \& Van Dyk, 2004:1). This view is confirmed by Cooper \& Van Dyk (2003:68) when they observe that this lack of academic success is evident in a large proportion of historically disadvantaged students because of '[a] number of socio-economic and political factors, rooted in the educational policies implemented during the era of the apartheid government'. Higher education institutions (HEIs) in South Africa are currently obliged through the National Plan for Higher Education (Ministry for Education, 2001) to address these inequalities by making tertiary education more accessible to all prospective students (Department of Education [DoE], 2001:4). Ntshoe (2002:7) also highlights the necessity for equity and redress in HEIs. The DoE (2001:47), however, also warns against the irresponsible action of merely doing away with so-called gate keeping actions by HEI's and admitting historically disadvantaged students simply to correct the diversity profile of the specific institution ${ }^{1}$.

A further reason for low levels of academic literacy may be that the South African educational system was a syllabus-driven (positivist) system. Within this system:

- Knowledge is considered to be universal, fixed, context free and neutral;

- The authority (teacher) is the sole source of information and his/her views are never challenged as he/she always knew best;

- Personal experience and culture or the known reality is the only valid frame of reference;

- The emphasis on left hemisphere activities leads mainly to a linear representation of thoughts; and

- Understanding is undifferentiated and all information is considered equally important.

(Blanckenberg, 1999; Bencze, 2005)

At present, teachers are caught between the positivist paradigms of the past and a constructivist approach (Blanckenberg, 1999). Teachers have generally not yet made the shift to social constructivist approach which underlies new developments, such as outcomes-based education (OBE). There are complex reasons for this, but the main one is that they lack the training and resources to do so. At present teachers vacillate between the old and the new approaches to teaching and learning.

Rademeyer (2005a: 41) poses the ironic possibility that OBE may cause learning problems for students since its purpose is to prepare learners for real life (authentic situations) and not necessarily for university education.

A third reason may be that an increasing number of university students choose to study in English, which is not necessarily their first language. An examination of the academic success rate of first and additional language users of English respectively, shows that a larger proportion of first language users of English are successful at the end of their first and further years of study (Butler \& Van Dyk, 2004:1) than their counterparts.

The situation at the University of Pretoria (UP), the largest residential university in South Africa, is no different from the situation described above. According to Webb (2002:50), 'A large percentage of the present-day students [at the UP] prefer English as language of learning and teaching (LoL/T)' Figure $1^{2}$ (adapted from Butler \& Van Dyk, 2004:2) 
illustrates this by providing details of the proportion of non-native vs. native users of English as language of learning at the UP. The graph shows the language status (native/non-native) of those who chose to write the academic literacy test in English:

A fourth reason is that students have limited access to the lexico-semantic meaning systems of academic English (cf. Starfield 2004).

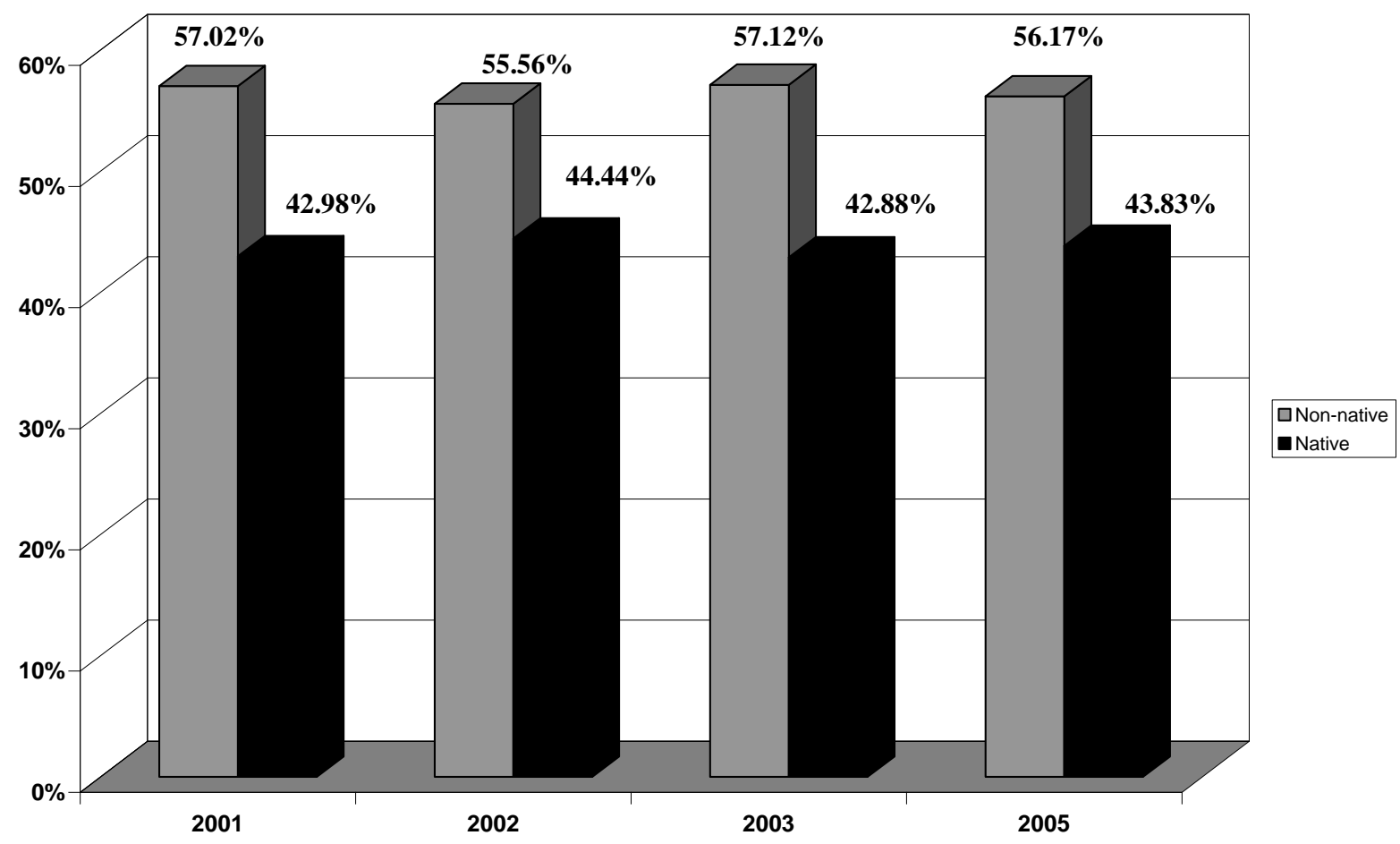

Figure 1: Non-native vs. native users of English at the University of Pretoria

\section{ADDITIONAL COMPLICATIONS FOR TERTIARY INSTITUTIONS}

Apart from the three possible reasons for academic failure, mentioned above, the situation in South Africa is currently rather complex as a number of additional factors may influence throughput rates and, consequently, financial losses.

The first of these is the claim by Yeld (2001:iii, 1) that the "South African Senior Certificate results [matric results] are not ... reliable predictors of academic success in Higher Education". Botha and Cilliers (1999), Paras (2001), Wood (1998), and Bargate (1999) also question the reliability of senior certificate results as indicators of academic success in higher education, as the dropout rate at universities increases every year. Nevertheless, HEIs still admit students on the basis of their matriculation results, since these are seen as adequate indicators of academic success (cf. Jawitz, 1995).

Secondly, given the developments that will see the current Senior Certificate, as well as the matriculation (university exemption) requirements that are based on it, replaced in 2008 by the general FETC (Further Education and Training Certificate) and the NSC (National Senior Certificate), there is as yet no indication that this situation will improve. 
Academically under-prepared students in the last instance contribute to universities losing vast amounts of money in subsidy, as a proportion of the subsidy is only obtained when a student graduates. The South African Higher Education subsidy system takes into consideration, amongst other things, four funding groups, four study levels and the number of historically disadvantaged enrolments at the concerned institutions (Vermeulen \& Melck, 2004). Universities are thus, to a certain extent, obliged to admit and accommodate (by means of various initiatives/mechanisms, one of which that will be discussed below in some more detail) more under-prepared students than in the past.

\section{A POSSIBLE SOLUTION}

The scenario outlined above compels universities to implement mechanisms to support under-prepared students (Botha \& Cilliers, 1999:144) by paying attention to post-enrolment factors, influencing academic success, such as low levels of academic literacy.

One such mechanism was the establishment of a language unit - the Unit for Academic Literacy (UAL) - at the University of Pretoria in an attempt to improve throughput rates by improving students' levels of academic literacy.

The UAL - initially called the Unit for Language Skills Development (ULSD) was set up in April 1999 to support students who are at risk of failing, because of too low a level of academic literacy / academic language proficiency. Policy implemented since 2000 at the UP requires that all students should be declared academically literate before graduating from this University (Van Dyk \& Weideman, 2004:3).

The first of three major responsibilities that the UAL is concerned with is the assessment of new first year students' academic literacy by means of a reliable, valid and standardised measuring instrument. Its second task is to supply adequate (language) support to those students who are at risk of not completing their studies in the minimum time allowed, by teaching fully credit-bearing language support courses to them. The ULSD is lastly required to teach several other language and language related courses to students who are not at risk, as determined by the academic literacy-measuring instrument. This includes courses like Academic reading, Academic writing, Legal discourse, Communication for organisations, Communication skills for engineers, etc.

The success of the UAL and its activities (for an overview, cf. Weideman 2003c) has been instrumental in convincing other universities to investigate and eventually implement a similar model at their institutions. Both the Universities of Stellenbosch and North West (Potchefstroom and Vaal Triangle campuses) have successfully done so, and there are examples at other universities of interventions of a more or less similar nature. Botha \& Cilliers (1999:144) argue that such actions are 'in line with international and national tendencies where universities endeavour to find their own standards to interpret the level of preparation of prospective students'.

The remainder of this article will focus on the first task of the UAL: the determination of students' academic literacy at the University of Pretoria by means of an academic literacy test, used for purposes of placement. The subsequent academic literacy intervention and a first glimpse of the effectiveness thereof will also be discussed. 


\section{ACADEMIC LITERACY TESTING AT THE UNIVERSITY OF PRETORIA}

As already noted, the UAL has annually, since 2000, administered a test of academic literacy /academic language proficiency to all first year students, in order to (a) determine their level of risk, and (b) to select and place those who qualify for additional support on appropriate courses.

Up to 2003, the ULSD used a commercially available test developed by Hough \& Horne Literacy Consultants. This test, the ELSA (English Literacy Skills Assessment) was initially intended for the industrial and commercial sector. The ELSA was later refined and adapted by both the developers and the UAL for use in the higher education sector. The 'new' test, the ELSA-Plus (English Literacy Skills Assessment for Higher Education and Training), assessed in accordance with its original purpose the 'competency input levels and trainability of students who need to function effectively in an English language environment' (Van Dyk \& Weideman, 2004:3).

\section{DESCRIPTION AND CONSTRUCT OF THE ELSA-PLUS}

In their discussion of the ELSA-Plus, Van Dyk \& Weideman (2004:3) highlight the following aspects: The ELSA-Plus is a skills-based, norm referenced (the first language user of English - or Afrikaans for purposes of the Afrikaans test - was used as the norm), standardised test used for placement purposes. It has a predictive validity of $84 \%$ and a reliability of 0.86 (Horne, 2002). It is furthermore a one-hour written assessment, which is objectively scored. It quantifies test subjects' language ability in terms of school grades, that is formal years of schooling - all first year students who for example displayed an inadequate level of language proficiency (grade 10 or below, that is 10 years of formal schooling) were required to enrol for compulsory, fully credit bearing language courses, offered by the UAL (Van Dyk \& Weideman, 2004:4). If a student measured on a grade 11 level or above, it indicated that he/she did not need any additional language support. The ELSA is also said to be culturally fair in that it avoids meta-language, colloquialisms, idiomatic expressions and dialectic usage (Horne, 2002). The ELSA-Plus consists on macro level of seven sections:

- Phonics (the ability to recognise and discriminate between English sounds);

- Dictation (the ability to write down spoken English (or Afrikaans) and adhere to academic writing conventions);

- Basic numeracy (where a familiarity with numbers is integrated with language use);

- Reading comprehension (both at elementary and intermediate levels);

- Language and grammar of spatial relations;

- A cloze procedure (the ability to create a semantic and coherent whole); and

- Vocabulary in context (the ability to extract information from a given context to infer the meaning of certain words or phrases).

\section{THE SUITABILITY OF THE ELSA-PLUS QUESTIONED}

The use of this test, however, has been questioned for a number of reasons, first among which were the logistical constraints in administering the test - the need for sophisticated sound equipment, stop watches, and an extended marking period for the number of students who sit 
the test (Van Dyk \& Weideman, 2004:4). This makes Elsa-Plus very expensive to administer.

A more important ethical consideration is that the construct of the ELSA-Plus test is based on an outdated and restricted view on language ability, which equates language ability with knowledge of sound, form, vocabulary and meaning, or 'in technical linguistic terms, phonological, morphological, syntactic and semantic elements' (Van Dyk \& Weideman, 2004:4,5). Shohamy (2004) warns of the dangers of using language tests that narrow language knowledge and create contradictions with existing views of knowledge. In the table below, the salient differences between a restrictive and an open view of language are summarised.

\begin{tabular}{|l|l|}
\hline Restrictive & \multicolumn{1}{c|}{ Open } \\
\hline Language is composed of elements: & Language is a social instrument to: \\
\begin{tabular}{rl|}
$\bullet \quad$ found \\
- meaning
\end{tabular} & $\begin{array}{r}- \text { mediate and } \\
- \text { in specific contexts }\end{array}$ \\
\hline Main function: expression & Main function: communication \\
\hline Language learning = mastery of & Language learning = becoming competent \\
structure & in communication \\
\hline Focus: language & Focus: process of using language \\
\hline
\end{tabular}

Table 1: Summary of the differences between a restrictive and an open view of language (from Weideman, 2003b: 38)

There are a number of implications for testing. The main one is that tests should require interaction with the focus on negotiation of meaning within specific contexts (Bachman \& Palmer, 1996: 61; Blanton, 1994:221). In this case, the true test is a test which shows the student's level of discourse competence in an academic context rather than a test which defines level of ability in terms of a skills-based approach. Bachman and Palmer (1996: 7576) conclude that 'language skills [should not be considered] to be part of language ability at all, but to be the contextualized realization of the ability to use language in the performance of specific language use tasks. We would ... argue that it is not useful to think in terms of 'skills', but to think in terms of specific activities or tasks in which language is used purposefully'.

For these and for a number of other minor reasons it was advisable for the UP to develop a test of academic literacy / academic language proficiency, which reflects more closely the extent to which students have acquired the ability to produce and interpret academic discourse.

\section{A NEW TEST CONSTRUCT}

After investigating and analysing three different, currently used (at national and international level), and highly recommended test constructs, the UAL in 2003 proposed a new construct 
(Van Dyk \& Weideman, 2004:7-12, and Weideman, 2003a:xi) for a placement test of academic literacy: the Test of Academic Literacy Levels (TALL).

\section{Definitions of test constructs}

A test construct defines the knowledge and/or abilities to be measured by that specific test. Davies, Brown, Elder, Hill, Lumley \& McNamara (1999: 31) define a test construct as 'an ability or set of abilities that will be reflected in test performance, and about which inferences can be made on the basis of test scores'. In line with Bachman \& Palmer's (1996:61-82) description of language ability, Douglas (2000: 111) defines a test construct as that part of a test that 'makes explicit the nature of the ability one wants to measure, including grammatical, textual, functional, and socio-linguistic knowledge, strategic competence, and background knowledge'.

\section{A new test construct for a test of academic literacy levels}

TALL requires of students at the micro level to be able to

- understand a range of academic vocabulary in context;

- interpret and use metaphor and idiom, and perceive connotation, word play and ambiguity;

- understand relations between different parts of a text, be aware of the logical development of (an academic) text, via introductions to conclusions, and know how to use language that serves to make the different parts of a text hang together;

- interpret different kinds of text type (genre), and show sensitivity for the meaning that they convey, and the audience that they are aimed at;

- interpret, use and produce information presented in graphic or visual format;

- make distinctions between essential and non-essential information, fact and opinion, propositions and arguments; distinguish between cause and effect, classify, categorise and handle data that make comparisons;

- see sequence and order, do simple numerical estimations and computations that are relevant to academic information, that allow comparisons to be made, and can be applied for the purposes of an argument;

- know what counts as evidence for an argument, extrapolate from information by making inferences, and apply the information or its implications to other cases than the one at hand;

- understand the communicative function of various ways of expression in academic language (such as defining, providing examples, arguing); and

- make meaning (e.g. of an academic text) beyond the level of the sentence.

(Weideman, 2003a:xi),

At a macro level, the test is divided into seven sections: scrambled text, academic vocabulary, graphic and visual literacy, text type (and register), reading comprehension, text editing, and writing.

Like Elsa-Plus, TALL is one-hour long and the scoring is done objectively. Its additional advantages are that it measures academic literacy and that it is cost effective. It is extremely reliable. Reliability refers to the consistency of test results (Nitko, 2001:62), or the actual agreement between the results of a test with itself (Davies, et al., 1999:168). For purposes of 
this article one estimation of reliability is used. TALL is expressed in terms of an alpha value $(\alpha)$ (see Table 2, below), as measured on several occasions and at different institutions. The alpha is an estimate of the likelihood that a test (TALL) would rank students in the same order from one administration to another and refers to the equation of Cronbach (Douglas, 2000:255). It is expressed on a scale of zero to one. The closer the value is to +1.0 , the more reliable the test is. Cronbach's $\alpha$ is defined as a measure that depicts the degree to which the observed scores represent the 'true' scores (i.e., without measurement error).

\begin{tabular}{|c|c|c|}
\hline Version of test and institution & & Alpha \\
\hline 2004, University of Pretoria & & 0.95 \\
\hline 2005, University of North West & & 0.94 \\
\hline 2005, University of Stellenbosch & & 0.89 \\
\hline 2005, University of Pretoria & & 0.93 \\
\hline 2006, Pilot 1, University of Pretoria & & 0.89 \\
\hline & Average & 0.92 \\
\hline
\end{tabular}

Table 2: Reliability measures

\section{How big is the problem?}

About one third of first year students at the Universities of North West (Potchefstroom and Vaal Triangle campuses), Pretoria and Stellenbosch (Table 3) are, according to TALL, at risk of not completing their studies in the prescribed time. This is consistent with data from the ELSA-Plus that was used up to 2003, as well as national data referred to in the first paragraph of this article.

\begin{tabular}{|c|c|c|c|c|c|c|}
\cline { 2 - 7 } \multicolumn{1}{c|}{} & $\mathbf{2 0 0 0}$ & $\mathbf{2 0 0 1}$ & $\mathbf{2 0 0 2}$ & $\mathbf{2 0 0 3}$ & $\mathbf{2 0 0 4}$ & $\mathbf{2 0 0 5}$ \\
\hline $\begin{array}{c}\text { UP } \\
\mathbf{N}=\mathbf{6 8 4 2}\end{array}$ & $28 \%$ & $33 \%$ & $27 \%$ & $29 \%$ & $31 \%$ & $31 \%$ \\
\hline $\begin{array}{c}\text { UNW } \\
\mathbf{N}=3224\end{array}$ & & & $31 \%$ & $33 \%$ & $30 \%$ & $31 \%$ \\
\hline $\begin{array}{c}\text { US } \\
\mathbf{N = 1 7 2 0}\end{array}$ & & & & & & $32 \%$ \\
\hline
\end{tabular}

Table 3: Percentage of first year students at risk

\section{How is the problem addressed?}

As explained above, the second task of the UAL is to support those students who are at risk (as indicated by TALL) of not completing their studies in the appropriate time and thus impeding throughput rates.

Academic literacy intervention at the University of Pretoria is aligned with the construct of TALL in that the syllabi are designed to meet the needs that are identified TALL - refer to Weideman (2003b) for a detailed description of the academic literacy course. The course is presented over a full academic year ( 28 weeks), with two lectures per week (100 minutes in 
total) contact time and approximately one and a half hours of homework per week. Every effort has been made to ensure that students take the course seriously and are able to attend. The course, which is fully credit bearing ( 12 credits), is added in to the students' programme of study, and is on the main timetable of the University. It is compulsory for all students whose test results on TALL indicated that they were at risk to do the course. Those who were not indicated as being at risk acquire the 12 credits by means of other language related/academic literacy related courses presented by the UAL and the School of Languages. This enables them to strengthen their academic literacy proficiency.

\section{How effective is the intervention?}

At this early point in time (it is only the second year since TALL and the associated courses have been introduced) only cautious conclusions are possible. It stands to reason that effective teaching in courses that are aimed to fill the gaps revealed on a particular test should allow students to perform better. What is more important is how well they did in the other courses they did. An even more important statistic would be how well students perform in their second and third years. What is necessary is a longitudinal study. With those provisos, the preliminary results are presented below.

Figure 2 illustrates the 2004 UP data for those who were identified as being at risk of failing $(\mathrm{N}=769)$ at the beginning of the year (first bar), compared to their results on exactly the same test after one year of academic literacy intervention (second bar). There was a noteworthy improvement, especially in the fields of coherence and cohesion (scrambled text), awareness of style, register, genre and text type (register and text type), as well as the ability to create a coherent whole (text editing). Note that this data is only for the English test. The third bar on the graph represents the English test population as a whole, as it is interesting to see how the at-risk-candidates performed initially against the group as a whole and how they improved, and in some instances (text type, text editing) even exceeded the initial average (third bar) of the group as a whole.

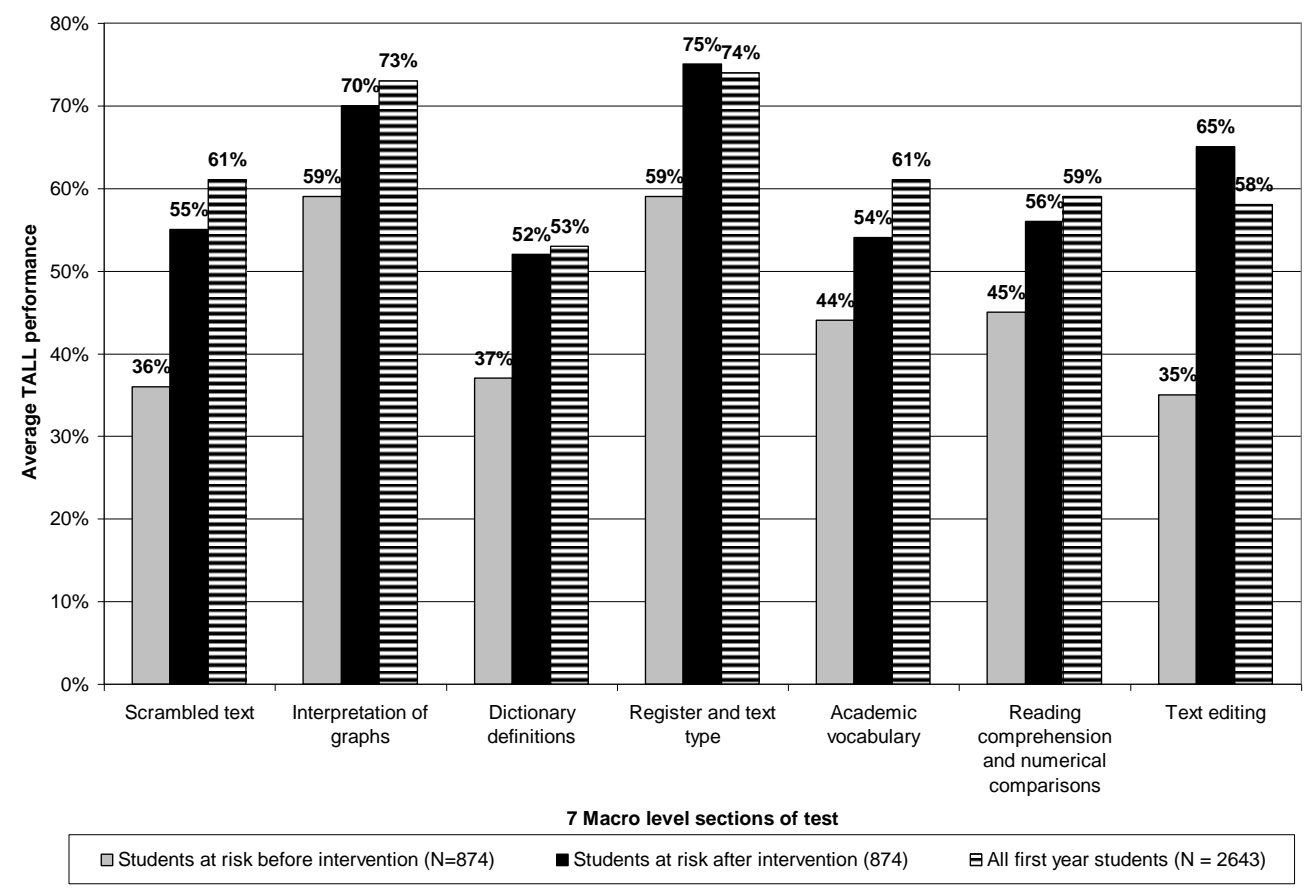

Figure 2: Test results: pre and post intervention 
Figures $3 \mathrm{a}$ and $3 \mathrm{~b}$ are histograms of the overall performance of the same group of at-risk students $(\mathrm{N}=769)$, presented in figure 2. Figure 3a represents the January distribution and figure $3 \mathrm{~b}$ the November distribution. It is evident from the figures that there was an improvement, in some cases even a considerable one. In January, the mean performance on TALL for this group of students was $41 \%$. In November, the mean performance improved to $58 \%$ which compares well with the mean of the total population in January (61\%). The cause of this improvement, however, still needs further investigation.

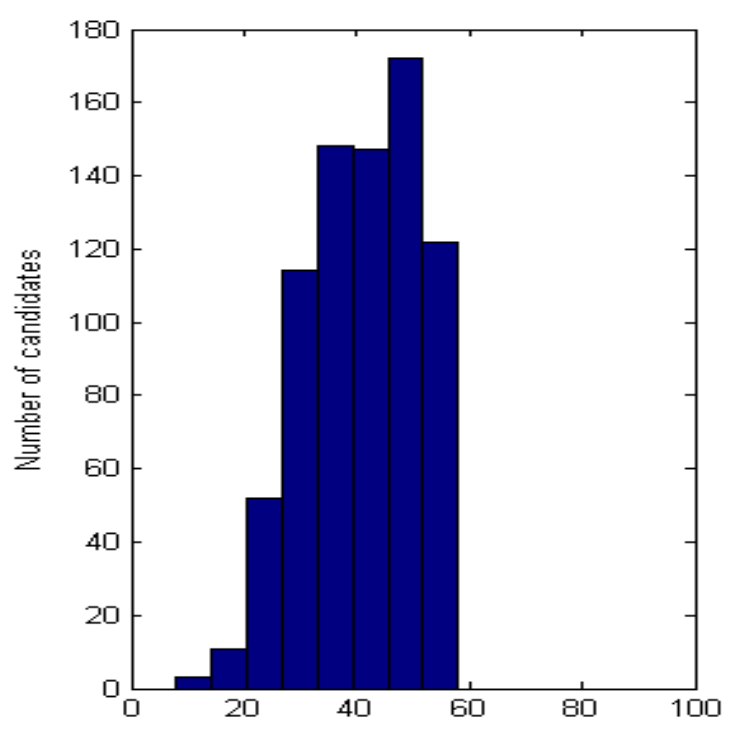

Figure 3a: January performance

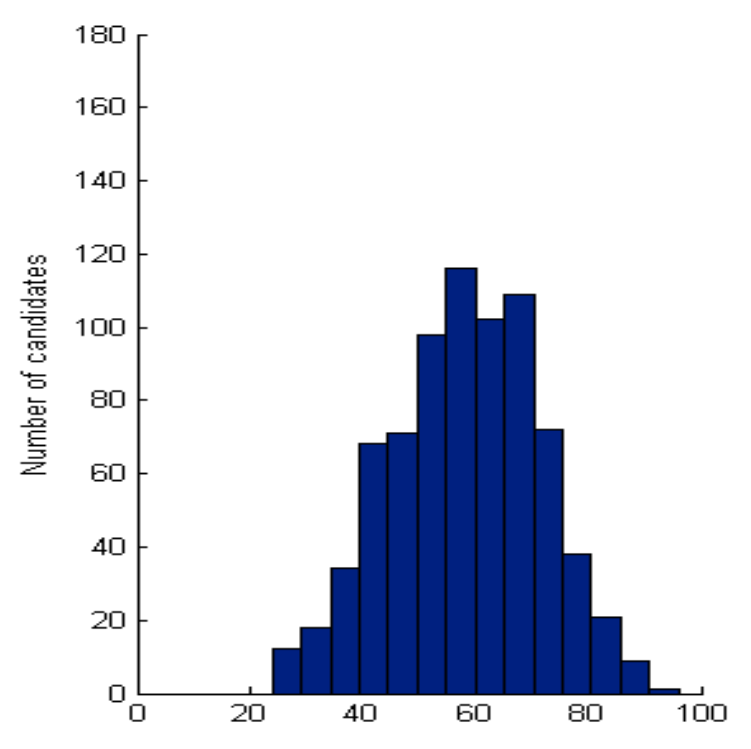

Figure 3b: November performance

A statistical hypothesis test was furthermore performed to determine if there is a significant linear correlation between the two data sets. A positive result was found $(\mathrm{N}=769, \mathrm{r}=0.654$, and $\mathrm{p}<0.001)$. At first glance this significant correlation could indicate that the November outcome was not influenced by the intervention - an insignificant correlation is usually expected if intervention occurred. However, it must be kept in mind that the subset of students who did receive the intervention, and who was tested again in November, is only the bottom third of the initial population. The data of students who did not receive any intervention were not included in this correlation test. The same subset of students received the same type of intervention. It can thus be expected that the performance in November should correlate significantly with the performance in January. It can be of value to perform a similar hypothesis test that includes data from the rest of the population to ascertain if the intervention had impact or not, based on the correlation coefficient.

\section{Further research}

In particular, there is a need to maintain and improve the reliability of TALL and to narrow the standard error of measurement, to validate and standardise the test, and to increase transparency in the design, use and outcomes of TALL (cf. Van der Slik \& Weideman 2005; Weideman 2005). As mentioned above, a longitudinal study is in process. For the longitudinal study TALL test data for the 2004, 2005, and 2006 intakes is/will be extracted. The academic performance for the same group of students for this study is/will be monitored and analysed over the extent of their complete undergraduate programme/studies, as well as 
for those students who did not undergo any academic literacy intervention. The following questions may be answered once the longitudinal study has been completed:

- What is the impact/effectiveness of the academic literacy courses? Do students just muddle through their studies and survive somehow, or do the academic literacy courses have a positive effect?

- What if students, after a year of academic literacy support, still do not achieve academic success? Is only one year of support enough? Should university access be revisited?

- What other variables, apart from academic literacy, have an influence on students' academic success and how is it addressed?

- What is the pass rate of students who had intervention and those who did not, by the end of first, second and third years of study?

- Is there a risk of teaching to the test, as the academic literacy syllabus is aligned with the test construct?

\section{CONCLUSION}

This article has discussed the current South African situation in terms of academic literacy, and the potential contribution that the (TALL) placement test followed by academic literacy support has on academic performance. The kind of support varies from institution to institution and depends on the level of risk as indicated by TALL at the three institutions where TALL is currently been employed. The preliminary results at the University of Pretoria are promising. Clearly the kind of examination, monitoring and even questioning of the validity of the testing process that this article reflects is essential in a multicultural, democratic society if the critical need for equity at tertiary institutions is to be met.

\section{END NOTES}

\footnotetext{
${ }^{1}$ It should be stated clearly that nowadays it is not only historically disadvantaged students who are at risk of not completing their studies in time. A growing number of traditionally white, so-called privileged students also are at risk of academic failure. From this point forward the term under-prepared will be used to refer to both historically disadvantaged and historically privileged students.

${ }^{2}$ The data used for Figure 1 comes from the databank (first year enrolments) of the Unit for Academic Literacy of the University of Pretoria. No electronic data was available for the 2004 intake, due to a change in the test used for assessing academic literacy.

${ }^{3}$ At the University of Pretoria the student has a choice of which one of the two languages of learning, i.e. Afrikaans or English, he/she wants to complete the test.
}

\section{REFERENCES}

BACHMAN, LF \& AS PALMER. 1996. Language testing in practice: Designing and developing useful language tests. Oxford: Oxford University Press.

BARGATE, K. 1999. Mathematics as an indicator of success in first year accounting programmes at Technikon Natal. South African Journal of Higher Education, 13(1):139-143. 
BENCZE, JL. 2005. Constructivism [Online]. Available: http://leo.oise.utoronto.ca/ lbencze/Constructivism.html [2005, December 9].

BLACQUIÉRE, A. 1989. Reading for survival: text and the second language student. South African Journal for Higher Education, 3(1):73-82.

BLANCKENBERG, HC. 1999. Die onderrig van Afrikaans as alternatiewe taal in 'n uitkomsgebaseerde onderwysbenadering. Ongepubliseerde VDO-Studiegids. Johannesburg: Nasionale Private Kolleges.

BLANTON, LL. 1994. Discourse, artefacts and the Ozarks: understanding academic literacy. Journal of second language writing 3 (1): 1-16. Reprinted (219-235) in Zamel, V \& R Spack (eds.), 1998. Negotiating academic literacies: teaching and learning across languages and cultures. Mahwah, New Jersey: Lawrence Erlbaum Associates, 235319.

BOTHA, HL \& CILLIERS, CD. 1999. Preparedness for university study: designing a thinking skills test. South African Journal of Higher Education, 13(1):144-152.

BUTLER, HG \& TJ VAN DYK. 2004. An academic English language intervention for first year engineering students. South African Journal of Linguistics, 22(1\&2):1-8.

COOPER, P \& TJ VAN DYK. 2003. Measuring vocabulary: A look at different methods of vocabulary testing. Perspectives in Education, 21(1): 67-80.

DAVIES, A, A BROWN, C ELDER, K HILL, T LUMLEY \& T MCNAMARA. 1999. Dictionary of language testing. Cambridge: Cambridge University Press.

DEPARTMENT OF EDUCATION. 2001. Education in South Africa: achievements since 1994. Pretoria: Department of Education.

DOUGLAS, D. 2000. Assessing languages for specific purposes. Cambridge: Cambridge University Press.

HORNE, TJ. 2002. Seminar delivered at the Unit for Language Skills Development, University of Pretoria. Unpublished remarks and discussion.

JAWITZ, J. 1995. Performance in first- and second-year engineering at UCT. South African Journal of Higher Education, 9(1):101-108.

LEIBOWITZ, B. 2001. Students' prior learning and their acquisition of academic literacy at a multilingual South African university. Unpublished $\mathrm{PhD}$ dissertation, University of Sheffield.

LEIBOWITZ, B. 2004. Becoming academically literate in South Africa: Lessons from student accounts for policymakers and educators. Language and Education, 18(1):3552. 
MACDONALD, CA. 1990. Crossing the threshold into standard three in black education: The consolidated main report of the threshold project. Pretoria: Human Sciences Research Council.

MAMAILA, K. 2001. R1,3bn spent on dropout students. Star 15 May, p1.

MINISTRY OF EDUCATION. 2001. National Plan for Higher Education. Pretoria: Ministry for Education.

MKHABELA, M \& M MALAN. 2004. By die 40\% eerstejaars druip. Skoksyfer kos belastingbetalers R1 miljard p.j. Rapport 26 September p. 2.

NATAL WITNESS. 2004. Illiterate matrics. Natal Witness, 27 September 2004: 8.

NITKO, AJ. 2001. Educational assessment of students. 3rd ed. New Yersey: Prentice-Hall, Inc.

NTSHOE, IM. 2002. National plan for higher education in South Africa: A programme for equity and redress or globalised competition and managerialism? South African Journal of Higher Education, 16(2):7-10.

PARAS, J. 2001. Crisis in mathematics education. Student failure: challenges and possibilities. South African Journal of Higher Education, 15(3):66-73.

PERKINS, DM. 1991. Improvement of reading and vocabulary skills at the University of Transkei. South African Journal of Education, 11(4):231-235.

PRETORIUS, EJ. 1995. Reading as an interactive process: Implications for studying through the medium of a second language. Communicatio, 21(2):33-43.

RADEMEYER, A. 2005a. Klas van 2008. Insig, 28 Februarie 2005:40.

RADEMEYER, A. 2005b. Te veel studente 'hoort nie werklik op universiteit': Tot soveel as 30\% van eerstejaars het nie vrystelling nie. Die Burger, 14 Mei 2005:4.

SHOHAMY, E. 2004. Assessment in muliticultural societies: Applying democratic principles and practices to language testing. In Norton, $\mathrm{K} \& \mathrm{~K}$ Toohey (eds), Critical pedagogies and language learning. Cambridge: Cambridge University Press, 72-92.

STARFIELD, S. 2004. 'Why does this feel empowering?' Thesis writing, concordancing, and the corporatizing university. In Norton, K \& K Toohey (eds), Critical pedagogies and language learning. Cambridge: Cambridge University Press, 138-157.

VAN DER SLIK, F \& AJ WEIDEMAN. 2005. The refinement of a test of academic literacy. Per Linguam, 21(1): 23-35.

VAN DYK, TJ \& AJ WEIDEMAN. 2004. Switching constructs: On the selection of an appropriate blueprint for academic literacy assessment. Journal for Language Teaching 38(1): 1-13. 
VAN RENSBURG, C \& A WEIDEMAN. 2002. Language proficiency: Current strategies, future remedies. Journal for Language Teaching, 36(1\&2):152-163.

VERHELST, ND. 2000. Estimating the reliability of a test from a single test administration. Measurement and Research Department Reports 98-2. Arnhem: National Institute for Educational Measurement.

VERMEULEN, P \& AP MELCK. 2004. The new funding framework: challenges for the University of Pretoria. Presentation delivered at the Senate Meeting of 28 January 2004, University of Pretoria. Unpublished remarks and discussion.

VORSTER, J \& T REAGAN. 1990. On the lexical development of L1 and L2 speakers. South African Journal of Linguistics, 9(3):80-84.

WEBB, VN. 2002. English as a second language in South Africa's tertiary institutions: A case study at the University of Pretoria. World Englishes, 21(1):49-69.

WEIDEMAN, AJ. 2003a. Academic literacy: Prepare to learn. Pretoria: Van Schaik.

WEIDEMAN, AJ. 2003b. Justifying course and task construction: design considerations for language teaching. Acta academica, 35(3):26-48.

WEIDEMAN, AJ. 2003c. Assessing and developing academic literacy. Per Linguam 19(1\&2): 55-65.

WEIDEMAN, AJ. 2005. Integrity and accountability in applied linguistics. Forthcoming in SA Linguistics and Applied Language Studies.

WOOD, T. 1998. Issues relating to the cognitive development of students at historically disadvantaged institutions. South African Journal of Higher Education, 12(1):87-94.

YELD, N. 2001. Assessment, equity and language of learning: Key issues for higher education selection in South Africa. Unpublished DPhil thesis, University of Cape Town.

\section{Biographic Note}

Tobie van Dyk lectures in the Unit for Afrikaans, Language Centre, Stellenbosch University. His research interests are language assessment and testing, and academic literacy development. He is the project manager for the TALL-initiative and serves on the National Benchmark Testing Project for academic literacy. email: tjvd@sun.ac.za 